\title{
A FURTHER COMPARISON OF GLACIER VELOCITIES MEASURED BY RADIO-ECHO AND SURVEY METHODS
}

\author{
By C. S. M. Doake, \\ (British Antarctic Survey, Cambridge $\mathrm{CB}_{3}$ oET, England) \\ M. Gorman \\ (Scott Polar Research Institute, Cambridge CB2 IER, England) \\ and W. S. B. Paterson \\ (Polar Continental Shelf Project, Department of Energy, Mines and Resources, Ottawa, \\ Ontario $\mathrm{K}_{\mathrm{I}} \mathrm{A}_{\mathrm{oE}}$, Canada)
}

\begin{abstract}
A comparison has been made between ice velocities that were measured by the radio-echo technique and by a survey method on the Devon Island ice cap, Arctic Canada (lat. $75^{\circ} 23^{\prime} \mathrm{N}$., long. $82^{\circ} 23^{\prime} \mathrm{W}$.). Results were $2.5^{8} \pm 0 . \mathrm{I}_{\mathrm{I}} \mathrm{a}^{-1}$ by radar and $2.17 \pm 0.20 \mathrm{~m} \mathrm{a}^{-1}$ by survey. The discrepancy between the two measurements is within the limits of statistical significance, and the methods are considered
to give comparable results.

Résumé. Une comparaison poussée entre les Mesures de vitesse de glaciers par écho-radio et par topographie. On a entrepris une comparaison entre les vitesses des glaces mesurées par écho-radio et par une méthode topographique sur la calotte de Devon Island dans l'Antarctique canadien. Les résultats sont de $2,58 \pm 0,13$ $\mathrm{m} \mathrm{a}^{-1}$ par radar et $2,17 \pm 0,20 \mathrm{~m}$ par levé. La discordance entre les deux mesures reste dans les limites le da signification statistique,"et les méthodes sont considérées comme donnant des résultats comparables.

Zusammenfassung. Ein weiterer. Vergleich zwischen radarseismisch und bzw. geodätisch bestimmten Gletschergeschwindigkeiten. Ein Vergleich zwischen radarseismisch bzw. geodätisch gemessenen Eisgeschwindigkeiten wurde für den Eisschild des Devon Island, kanadische Arktis, angestellt. Die Radar-Echolotung ergab $2.5^{8} \pm$ o. I $\mathrm{m}$ pro Jahr, die Vermessung $2.17 \pm 0.20 \mathrm{~m}$ pro Jahr. Der Unterschied zwischen beiden Messungen liegt innerhalb der Grenzen für statistische Signifikanz. Die Ergebnisse beider Methoden können als vergleichbar gelten.
\end{abstract}

\section{INTRODUGTION}

Nye and others (1972) have suggested that the surface velocity of a glacier can be determined from radio-echo fading patterns. The method is based on the fact that the shape of the reflected radio pulse depends on the roughness of the glacier bed. The spatial pattern of the variation in shape of the reflected signal thus provides a frame of reference fixed in space. The apparent displacement of this pattern over a given time interval, in the vicinity of a stake set in the ice, thus measures the ice velocity.

Walford (1972) made the first field test of the method on Fleming Glacier in the Antarctic Peninsula. In addition to the radio-echo method, ice velocity was measured by conventional optical survey to stations on bedrock near the glacier. The survey velocity was I.2 I times the radio-echo velocity; Walford attributed the discrepancy to experimental errors. Doake (r975) repeated the experiment at a place within $2 \mathrm{~km}$ of Walford's site and obtained the result that the survey velocity was I.4I times the radio-echo velocity (the radio-echo velocities agreed in the two measurements). Doake considered that the difference was significant and postulated that the radio waves were being reflected, not from bedrock, but from a layer embedded in the basal layers of the glacier. The radio-echo method thus measured only the velocity resulting from deformation within the ice whereas the optical measurement also included the component of velocity due to the ice sliding over its bed.

In view of these different interpretations, the results of a test at a place where the ice is not sliding over bedrock may be of interest. We present these here. 


\section{SITE OF EXPERIMENT}

The measurements were made on the ice cap (area about ${ }_{5} 500 \mathrm{~km}^{2}$ ) that covers the eastern part of Devon Island in the Canadian Arctic archipelago. The main ice divide consists of an east-west ridge from which ice flows into valley glaciers that reach the sea on the north, east, and south coasts. Three bore holes, two of which reach bedrock, have been drilled at distances of $600 \mathrm{~m}$ to $900 \mathrm{~m}$ north of the ridge at a point some $8 \mathrm{~km}$ west of the highest point (Paterson, 1973, r 974). Interpretation of the bore-hole data required knowledge of the ice velocity. As the nearest exposed bedrock from which a survey traverse could be carried out was about $35 \mathrm{~km}$ away, the radio-echo technique seemed the simplest method of determining ice velocity. Because the measured temperature at the ice-rock interface was $-18.5{ }^{\circ} \mathrm{C}$ (Paterson, 1973), there can be no pressure-melting and regelation and so the ice cannot be sliding over its bed. The cores recovered from the bore holes showed a sharp interface between ice and rock with no moraine in the lowest layers of ice. The radio-echo method should thus measure the total ice velocity.

Because the bore holes were near the ice divide, where the velocity may be expected to be small, a time period of a few years would have been necessary to obtain an accurate result. Measurements were therefore made at a point about $2.5 \mathrm{~km}$ down-slope from the bore holes. This point was connected to the bore holes and the ice divide by a line of stakes about $300 \mathrm{~m}$ apart plus four diamond-shaped arrays of stakes, one on the ice divide, one each around two of the bore holes, and one around the point where the radio-echo measurements were made (Fig. I). The radar measurement of velocity could thus be checked from the strain-rate measurements along the line of stakes on the assumption that the velocity was zero at the ice divide.

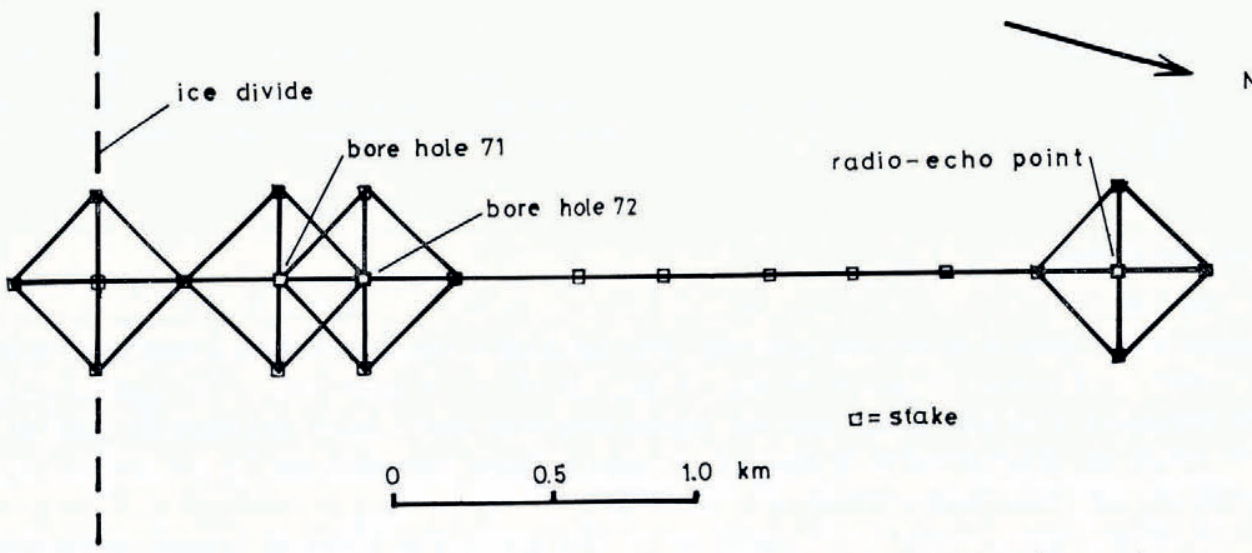

Fig. I. Map showing locations of the velocity measurement point, the bore holes, and the stake network.

\section{RADIO-ECHO MEASUREMENTS}

Equipment and procedure were broadly similar to those described by Walford (1972) and Doake (1975). Our measurements differed from theirs primarily in the use of a $6 \mathrm{o} \mathrm{MHz}$ radio-frequency carrier frequency (which provides improved resolution), and an interval of about one year between fading pattern measurements as opposed to the few days which they describe.

The radio-echo equipment used was the SPRI Mk IV 6o MHz system, which is a development of the system described by Evans and Smith (1969). The significant parameters include a transmitted pulse length of $\mathrm{I} \mu$ s with a peak power of about $300 \mathrm{~W}$, a receiver bandwidth of I $5 \mathrm{MHz}$, and a system performance of $\mathrm{I} 6 \mathrm{odB}$. The use of a I $\mu$ s pulse length has a definite 
advantage over the $0.3 \mu$ s reported previously, in that it gives a bottom echo of greater duration. Walford showed that the fading pattern had a well-defined periodic fading length which decreased with time from the start of the echo. Therefore longer pulse lengths, giving longer echoes, will produce spatial patterns with a greater range of fading lengths. The increased structure gives more detail in the fading pattern which can be used as a basis for comparison. The antenna used was a folded dipole.

The fading patterns were recorded on film in the usual $Z$-scope display. A modified timing arrangement was used so that the display could be adjusted to include only the bottom echo. The measurement routine was essentially that of Doake (1975). The antenna was supported a few centimetres above the ice on a "railway", constructed of glass-fibre tubing and aligned to $344^{\circ}$ from true north, the measured direction of flow. The antenna was then moved steadily along the railway, recording the fading pattern. Repeated traverses were made, with the antenna shifted laterally each time by an average of $20 \mathrm{~cm}$. Thus the fading pattern was mapped over an area $8 \mathrm{~m} \times 2 \mathrm{~m}$. To provide an accurate and repeatable distance scale for each traverse, pins were fixed every $20 \mathrm{~cm}$ into the side of the track. These were successively contacted by a switch mounted with the antenna. Each switch closure annotated the film by means of a light-emitting diode mounted on the oscilloscope screen, thus recording the position of the antenna at that instant.

Fading patterns were obtained on 23 June 1973 and again on 5 June r974. The positions of five different features in the patterns were compared on up to i4 different traverses. A total of 69 displacements gave the movement as $2.5^{8} \mathrm{~m} \mathrm{a}^{-1}$ with a standard error of $0.03 \mathrm{~m} \mathrm{a}^{-1}$. The error figure refers only to the comparison of the fading patterns. This does not include any possible systematic error that may occur, for example, in the relocation of the railway. The railway position was marked by a metal stake, so the greatest error in repositioning was unlikely to exceed $10 \mathrm{~cm}$, making the error figure $0.1 \mathrm{I} \mathrm{m} \mathrm{a}^{-1}$.

\section{Strain-RATE measurements}

In the strain diamonds, all sides and diagonals were measured with invar tape and the angles were measured with a Wild $\mathrm{T}_{2}$ theodolite. Measurements were made in I971, 1972 and 1973. The data were reduced by Nye's (1959) method. Distances along the stake line were also measured by invar tape, but in 1971 and 1972 only. Strain-rates in the down-slope direction were in the range $(0.4$ to $\mathrm{I} .2) \times \mathrm{IO}^{-3} \mathrm{a}^{-1}$ whereas cross-slope strain rates were about an order of magnitude less $(0.06$ to 0.14$) \times \mathrm{IO}^{-3} \mathrm{a}^{-1}$. The mean standard error of a strainrate, as determined from the analysis of the strain diamonds, was $0.08 \times \mathrm{IO}^{-3} \mathrm{a}^{-1}$ and so the cross-slope strain-rates did not differ significantly from zero. Summation of the product of strain-rate and distance between adjacent stakes, starting at the ice divide, should therefore determine the flow velocity. The simpler procedure of taking the change in total length of the stake line as the velocity could not be used because, in each year, different sections of the line were measured on different days. The direction of ice flow, bearing $344^{\circ} \pm 5^{\circ}$ from true north, was determined from the strain measurements.

The location of the crest of the ridge that forms the ice divide was determined by levelling. The assumption of zero ice velocity at this point was checked in the following way. The strainrates from the ice divide to bore hole 72 , located $900 \mathrm{~m}$ down the slope, yielded a velocity of $0.74 \pm 0.05 \mathrm{~m} \mathrm{a}^{-1}$. Inclinometer measurements in the bore hole, which reaches bedrock, gave a velocity of $0.70 \pm 0.20 \mathrm{~m} \mathrm{a}^{-1}$, on the plausible assumption that there was no bottom sliding. The close agreement between these figures suggests that the assumption of zero velocity at the ice divide was correct.

With the above assumption, the measured strain-rates and distances between stakes from the ice divide to the point where the radio-echo measurements were made yield a velocity of $2.17 \pm 0.20 \mathrm{~m} \mathrm{a}^{-1}$. 


\section{Conclusions}

The apparent ice velocity was $2.58 \pm 0.1 \mathrm{I} \mathrm{m} \mathrm{a}^{-1}$ by radar and $2.17 \pm 0.20 \mathrm{~m} \mathrm{a}^{-1}$ by survey. While a value between 2.36 and $2.47 \mathrm{~m} \mathrm{a}^{-1}$ is within twice the standard error limits of each measurement, the discrepancy between the results is large enough to be on the borderline of statistical significance. Unlike the previous experiments (Walford, 1972; Doake, 1975), in Devon Island the radar velocity was the higher. The reason is probably that part of the stake line did not coincide with the flow line. In this case the measured strain-rate would be less than the greatest principal strain-rate and so the survey method would underestimate the velocity. Another possible explanation is that a small error was made in resetting the track for the radio-echo antenna in the second year. The radar method is probably the more precise and so is to be preferred, at least at places far from exposed bedrock.

\section{Acknowledgement}

The radio-echo measurements form part of a broad programme of "Radio-echo studies of polar ice sheets" being undertaken by the Scott Polar Research Institute with finance from the Natural Environment Research Council of the United Kingdom. Co-operation and help from the British Antarctic Survey and from the Polar Continental Shelf Project, Department of Energy, Mines and Resources, which provided logistic support, is gratefully acknowledged.

MS. received 22 August 1975 and in revised form 24 September 1975

\section{REFERENCES}

Doake, C. S. M. 1975. Glacier sliding measured by a radio-echo technique. Fournal of Glaciology, Vol. 15, No. 73,

p. 89-93.
Evans, S., and Smith, B. M. E. 1969. A radio echo equipment for depth sounding in polar ice sheets. Fournal of Scientific Instruments (Journal of Physics, E), Ser. 2, Vol. 2, No. 2, p. 131-36.

Nye, J. F. I 959. A method of determining the strain-rate tensor at the surface of a glacier. Fournal of Glaciology,

Vol. 3, No. 25, p. 409-19.
Nye, J. F., and others. 1972. Proposal for measuring the movement of a large ice sheet by observing radio echoes, by J. F. Nye, R. G. Kyte and D. C. Threlfall. Journal of Glaciology, Vol. I I, No. 63, p. 319-23.

Paterson, W. S. B. 1973. Recent work: Canada. Ice, No. 41, p. $2-8$.

[Paterson, W. S. B.] 1974. Recent work: Canada. Ice, No. 44, p. 2-1o.

Walford, M. E. R. 1972. Glacier movement measured with a radio echo technique. Nature, Vol. 239, No. 5367, p. $93-95$. 